\title{
PENERAPAN WEBSITE E-COMMERCE BERBASIS CONTENT MANAGEMENT SYSTEM (CMS) PADA Q-TA DIGITAL PRINTING
}

\author{
Ananda Dian Nugraha ${ }^{1)}$, Gandung Triyono ${ }^{2)}$ \\ ${ }^{1}$ Sistem Informasi, Fakultas Teknologi Informasi, Universitas Budi Luhur \\ 1,2 Jl. Raya Ciledug, Petukangan Utara, Kebayoran Lama, Jakarta Selatan 12260 \\ E-mail : anandadian.nugraha@gmail.com ${ }^{1)}$, gandung.triyono@budiluhur.ac.id ${ }^{2}$
}

\begin{abstract}
Abstrak
Pemasaran melalui e-commerce kepada konsumen pada umumnya beroperasi berdasarkan prinsip pemasaran massa dan pemasaran ke bisnis untuk membangun tenaga pemasaran yang tebaik melalui internet. Q-ta Digital Printing adalah sebuah toko yang bergerak dibidang jasa percetakan yang menawarkan pelayanan pencetakan offset. Toko ini hanya memiliki pelanggan yang tersebar di dalam kota Depok saja. Pada toko ini sudah menggunakan teknologi komputer untuk mendukung operasinya seperti mendesain produk pesanan konsumen. Namun penggunaan teknologi komputer masih terbatas hanya untuk operasi bisnis saja dan tidak menggunakan internet sebagai lahan penjualan dan promosi. Tidak adanya laporan bulanan juga mempengaruhi kinerja toko. Dengan dibuatkannya media website e-commerce yang dapat mengelola produk Q-ta Digital Printing yang dianalisa dengan metode business model canvas, serta memberikan strategi pemasaran melalui internet dalam hal ini menggunakan Search Engine Optimization (SEO) yang akan meningkatkan pemasaran produk dan memudahkan konsumen dalam berbelanja dengan mengaplikasikan konsep e-commerce menggunakan Content Management System (CMS) dari WordPress untuk memudahkan pelayanan pemesanan secara online. Penerapan website e-commerce ini juga menghasilkan 5 laporan yaitu laporan penjualan, laporan barang terlaris, laporan pengiriman, laporan pembayaran, dan rekapitulasi penjualan.
\end{abstract}

Kata kunci: E-Commerce, Business Model Canvas (BMC), Content Management System (CMS), Percetakan Offset

\section{PENDAHULUAN}

Manusia dengan mudah dapat menyampaikan dan memperoleh berbagai informasi. Dengan internet, manusia dapat berbisnis dengan mudah. Melalui e-commerce, pelaku bisnis dalam perusahaan cenderung ingin mendapatkan pemasaran yang efektif dan efisien sebagai sarana informasi. Q-ta Digital Printing adalah sebuah toko yang bergerak dibidang jasa percetakan yang menawarkan berbagai macam pelayanan cetak offset. Toko ini memiliki pelanggan yang tersebar di dalam kota Depok, namun penggunaan teknologi komputer masih terbatas dan belum memanfaatkan teknologi internet dalam hal ini e-commerce untuk mendukung kemajuan pemasaran dan penjualan bisnis. Masalah yang ditemukan pada Q-ta Digital Printing adalah pelanggan yang hanya datang dari domisili Kota Depok, tidak adanya laporan penjualan bulanan, dan promosi melalui mulut ke mulut maupun aplikasi WhatsApp yang kurang efektif.

\section{LANDASAN TEORI}

\subsection{E-Commerce}

Suyanto mengatakan Electronic commerce (ecommerce) adalah konsep terbaru yang digambarkan sebagai proses jual beli produk atau jasa pada World Wide Web atau proses jual beli atau pertukaran produk, jasa dan informasi melalui jaringan informasi internet [1].

\subsection{Business Model Canvas (BMC)}

Menurut Osterwalder \& Pigneur, business model canvas adalah metode yang berguna untuk mendeskripsikan, merancang, dan menganalisa pemodelan bisnis suatu perusahaan. Serta bisa digunakan untuk menentukan transformasi model bisnis suatu perushaan. BMC digunakan untuk mendeskripsikan dan mengidentifikasi model bisnis yang sedang berjalan maupun membuat strategi bisnis baru [2].

\subsection{Content Management System (CMS)}

CMS adalah software yang dibangun khusus untuk membuat toko di dunia maya yang sering disebut E-Commerce. Dengan CMS, admin dapat mengatur content pada website seperti teks, foto, suara, video, dan semua file type yang dipublish di website [3].

\subsection{Penelitian Terkait}

Penelitian oleh [4] menjelaskan pada studi kasus Toko KUN, permasalahan yang dihadapi adalah media promosi hanya menggunakan spanduk, penjualan masih offline, penyimpanan data dan pencetakan laporan masih berupa pencatatan berbentuk arsip. Tujuan penelitian yang dilakukan 
adalah memberi solusi pemecahan masalah yang ada dengan merancang sistem informasi penjualan $e$ commerce. Hasil dan kesimpulan dari penelitian ini berupa website penjualan berbasis e-commerce dapat dijadikan untuk wadah promosi, mempermudah proses transaksi secara online, serta dalam pengolahan dan pencetakan laporan yang tidak lagi memerlukan pencatatan dalam bentuk arsip.

Penelitian yang dilakukan oleh [5] dalam pembuatan situs e-commerce untuk penjualan miniatur bus. Masalah yang ditemukan bagi konsumen adalah konsumen harus datang langsung ke home industri yang dianggap kurang efektif karena bagi konsumen yang berada di luar kota membutuhkan waktu dan biaya yang banyak. Dengan kekurangan yang ada, peneliti menemukan ide untuk membuat situs e-commerce untuk mempermudah konsumen dalam melakukan pemesanan produk.

Penelitian oleh [6] pada pengrajin kursi sofa Cipancing ditemukan masalah seperti produk yang dihasilkan tidak terlalu dikenal oleh masyarakat dan kurang adanya perhatian dari pemerintah daerah setempat. Keterbatasan kemampuan SDM, modal, dan pemasaran yang masih dilakukan dengan cara tradisional menyebabkan para pengrajin sulit berkembang. Penelitian yang dilakukan untuk mengetahui sejauh mana bisnis ini sudah berjalan dan mencari pemecahan masalah dengan menggunakan Business Model Canvas dan analisis SWOT. Hasil penelitian menghasilkan kerja sama antar pengrajin kursi sofa dan dukungan pemerintah menjadi alternatif untuk mengatasi permasalahan pada blok bangunan Business Model Canvas.

Dari segi kesamaan penelitian, pemecahan masalah dilakukan dengan membuat e-commerce dan menggunakan business model canvas. Perbedaan penelitian ini dengan penelitian yang sebelumnya adalah menggunakan CMS, dan menggunakan search engine optimization (SEO) untuk pemasaran produk pada Q-ta Digital Printing.

\section{MODEL USULAN}

\subsection{Business Model Canvas}

Model usulan pada Q-ta Digital Printing digambarkan melalui Business Model Canvas.

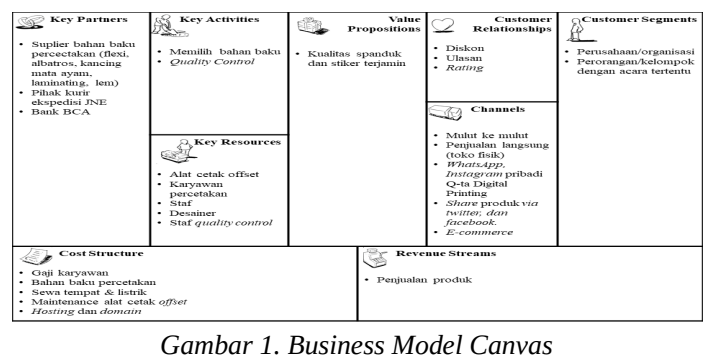

Berikut merupakan penjabaran elemen business model canvas yang diaplikasikan:

1. Value Propositions

Kualitas cetakan spanduk dan stiker terjamin merupakan keunggulan bisnis Q-ta Digital Printing.

2. Customer Segment

Target bisnis yang difokuskan dari Q-ta Digital Printing adalah perusahaan, organisai, perorangan, dan kelompok dengan acara tertentu.

3. Revenue Stream

Penjualan produk merupakan profit yang didapat Q-ta Digital Printing

4. Key Activities

Memilih bahan baku dan quality control.

5. Key Resources

Sumber daya yang digunakan adalah komputer, alat cetak offset, staf, desainer, dan staf quality control.

6. Customer Relationship

Customer relationship yang diterapkan yaitu diskon pada toko, ulasan, dan rating.

7. Channels

Strategi marketing yang dilakukan oleh Q-ta Digital Printing yaiti promosi mulut ke mulut, aplikasi WhatsApp, Instagram toko, website $e$ commerce, serta share produk pada media sosial facebook, dan twitter.

8. Key Partners

Q-ta Digital Printing bekerjasama dengan suplier bahan baku percetakan, bekerjasama dengan pihak kurir ekspedisi JNE untuk melakukan pengiriman produk, dan Bank BCA untuk pembayaran.

9. Cost Structure

Biaya yang dikeluarkan oleh Q-ta Digital Printing yaitu untuk membeli bahan baku percetakan, membayar sewa tempat dan listrik, membayar gaji karyawan, dan maintenance alat cetak offset.

\subsection{Use Case Diagram}

Fungsi pada model usulan digambarkan dengan use case diagram. Berikut ini use case yang akan diterapkan pada Q-ta Digital Printing.

a. Use Case Diagram Account

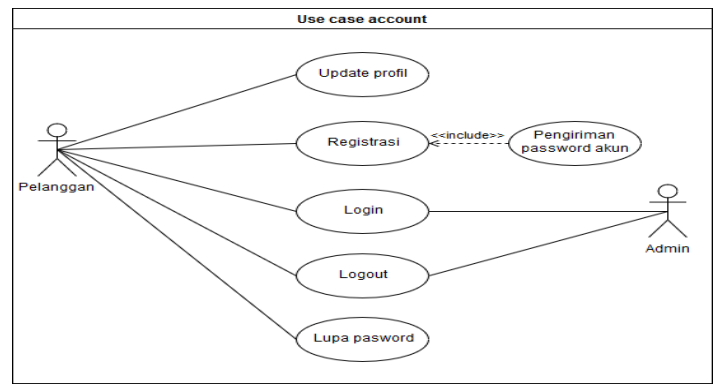

Gambar 2. Use Case Diagram Account 
Pada Gambar 2 terdapat update profil, registrasi akun, login, ubah password, dan lupa password. Aktor use case diagram account adalah Pelanggan, Admin, dan Pemilik

b. Use Case Diagram Master Pelanggan

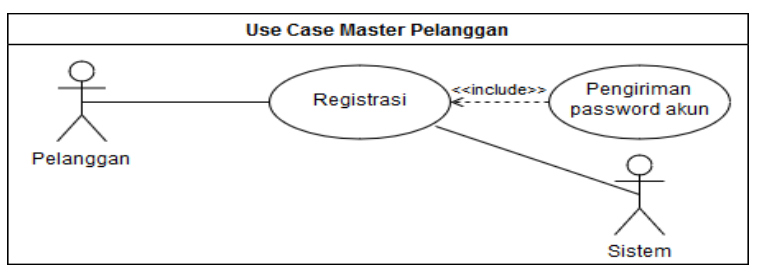

Gambar 3. Use Case Diagram Master Pelanggan

Pada Gambar 3 terdapat use case diagram master pelanggan yang terdiri dari registrasi, dan notifikasi email password. Aktor use case diagram master pelanggan adalah Pelanggan dan Sistem.

c. Use Case Diagram Master Admin

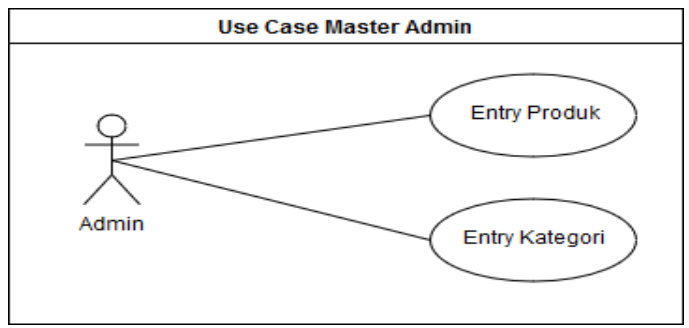

Gambar 4. Use Case Diagram Master Admin

Pada Gambar 4 terdapat use case diagram master admin yang terdiri dari admin sebagai aktor yang mempunyai akses untuk entry produk, dan entry kategori.

d. Use Case Diagram Pemesanan

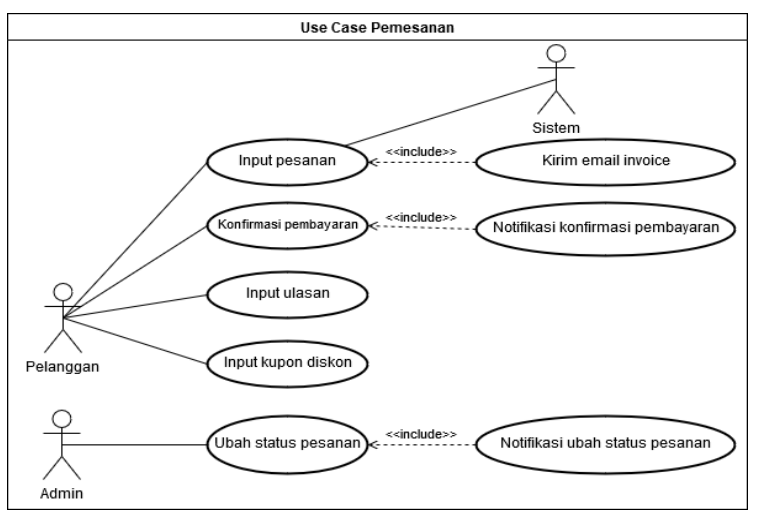

Gambar 5. Use Case Diagram Pemesanan

Pada Gambar 4 terdapat input pesanan, konfirmasi pembayaran, input ulasan dan input kupon oleh pelanggan, dan ubah status pesanan oleh admin.

e. Use Case Laporan

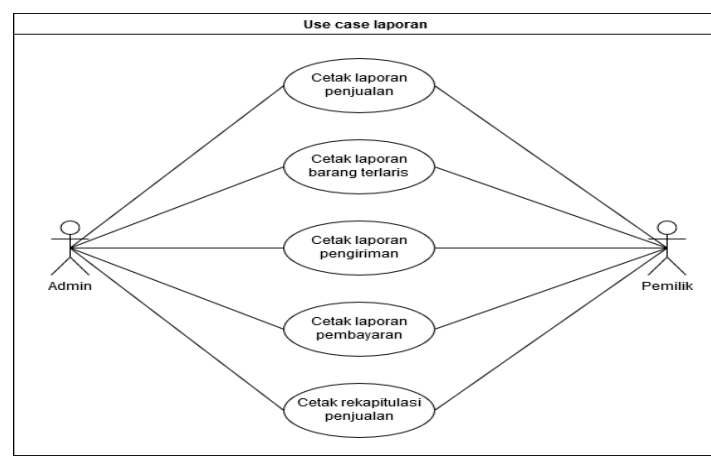

Gambar 6. Use Case Laporan

Pada Gambar 5 terdapat cetak laporan penjualan, cetak laporan pembayaran, cetak laporan pendapatan, cetak laporan pengiriman, dan cetak rekapitulasi penjualan oleh Admin dan Pemilik

\subsection{Rancangan Layar}

Rancangan layar merupakan perencanaan tampilan kepada user dengan menggunakan balsamiq mockup. Berikut adalah rancangan layar pada website Q-ta Digital Printing :

a. Tampilan Menu

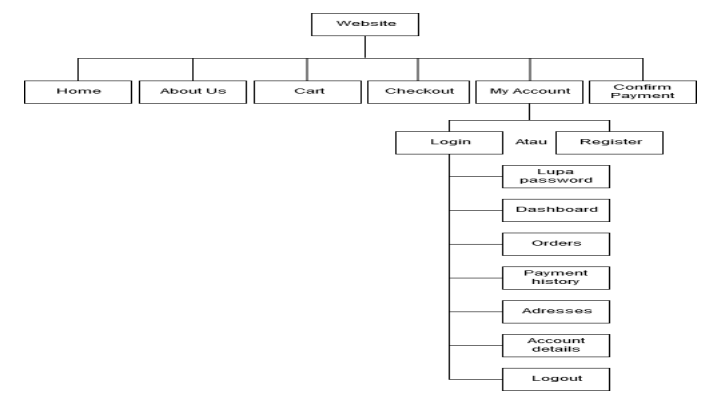

Gambar 7. Tampilan Menu

Gambar 7 menunjukkan tampilan menu pada website e-commerce Q-ta Digital Printing yang berisi home, about us, cart, checkout, confirm payment, dan my account yang memiliki sub menu lupa password, dashboard, orders, payment history, account details, serta logout.

b. Home

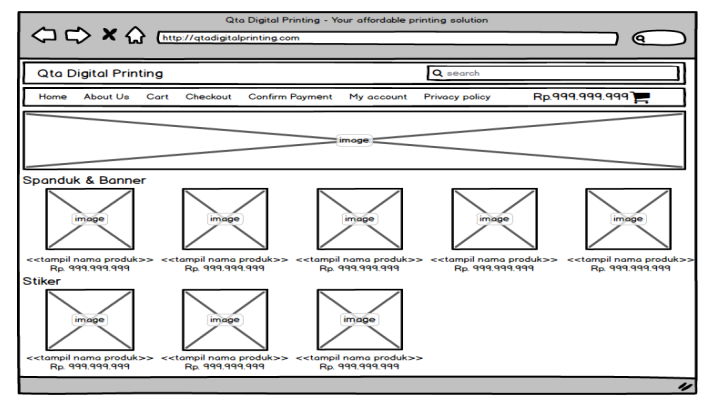

Gambar 8. Rancangan Layar Home 
Gambar 8 menunjukkan rancangan layar home pada website yang memiliki navigation bar yang berisikan home, about us, cart, checkout, confirm payment, my account (untuk login dan registrasi, serta dashboard akun), dan privacy policy, serta katalog produk yang dijual.

\section{c. Login dan Register}

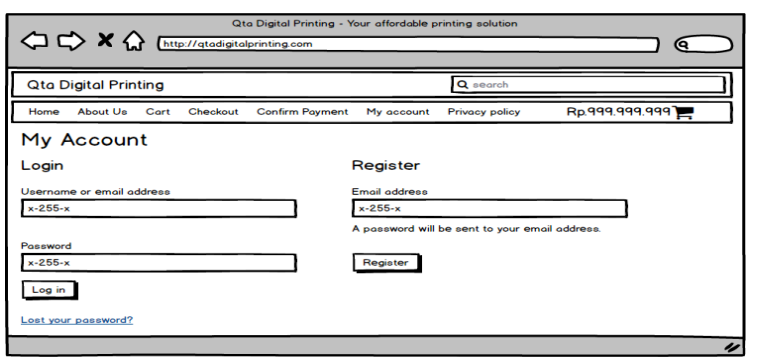

Gambar 9. Rancangan Layar Login dan Register

Pada Gambar 9 rancangan layar login dan register terdapat textbox username/email dan password untuk login ke dalam website. Pada form register terdapat textbox email untuk mendaftar pada website.

\section{d. Lupa Password}

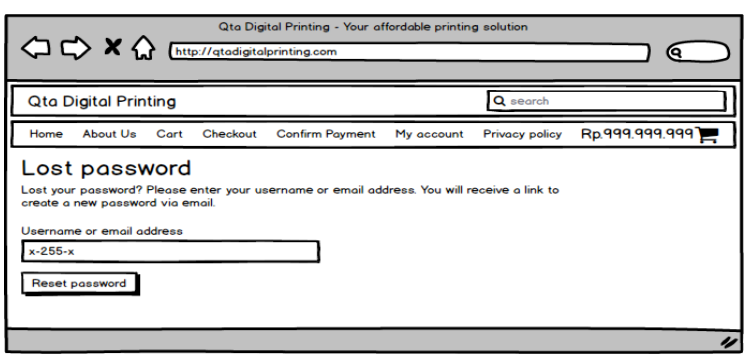

Gambar 10. Rancangan Layar Lupa Password

Rancangan layar pada Gambar 10 menunjukkan halaman lupa password yang berisi textbox username/email address untuk peresetan password.

\section{e. Orders}

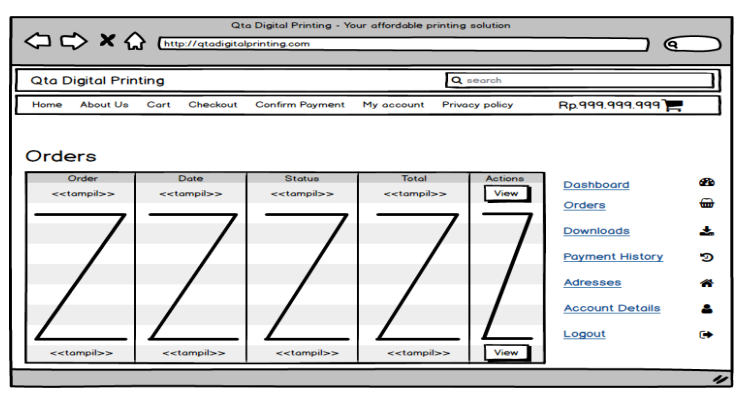

Gambar 11. Rancangan Layar Orders

Rancangan layar orders berisi detil produk dan status produk yang sudah dibeli oleh pelanggan.

\section{f. Payment History}

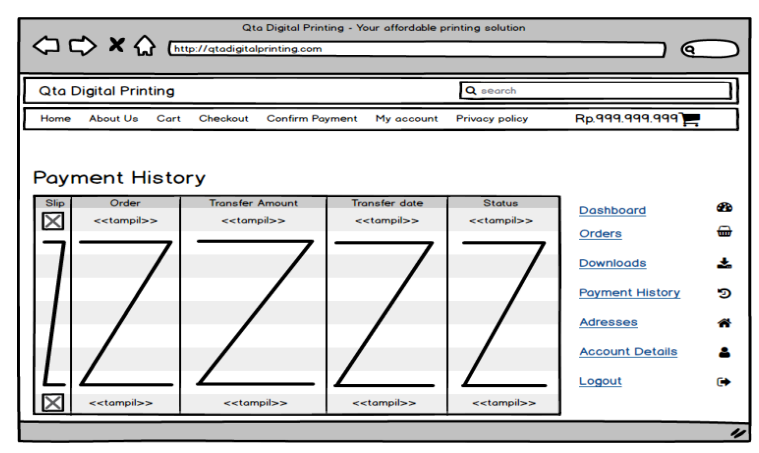

Gambar 12. Rancangan Layar Payment History

Rancangan layar payment history pada Gambar 11 terdapat histori pembayaran pelanggan.

\section{g. Account Details}

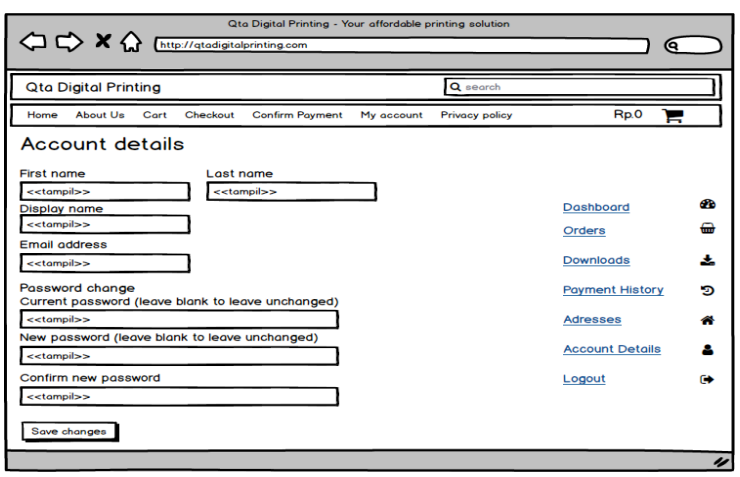

Gambar 13. Rancangan Layar Account Details

Rancangan account details pada Gambar 13 terdapat menu dashboard, orders, downloads, payment history, addresses, account details, dan logout.

h. Detil Produk

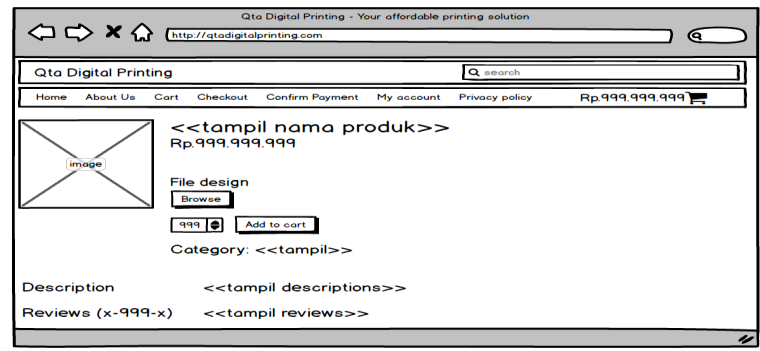

Gambar 14. Rancangan Layar Detil Produk

Pada Gambar 14 menunjukkan rancangan layar detil produk terdapat detil produk yang berisi nama, gambar, deskripsi, dan ulasan produk.

i. Shopping Cart 


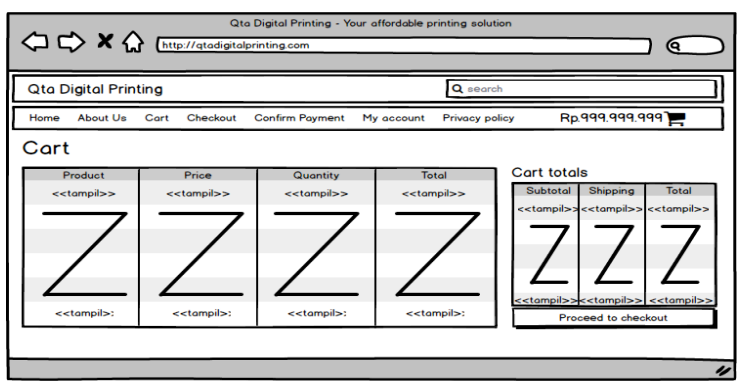

Gambar 15. Rancangan Layar Shopping Cart

Rancangan layar shopping cart terdapat detil produk yang dipesan. Di dalam tabel produk terdapat product, price, quantity, dan total.

j. Checkout

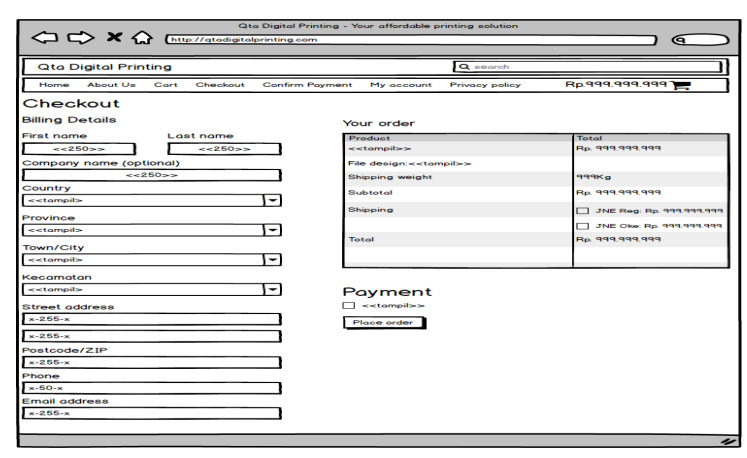

Gambar 16. Rancangan Layar Checkout

Rancangan layar checkout terdapat form detil pengiriman produk, detil produk yang dipesan, dan payment method. Tombol place order untuk melakukan pembayaran.

k. Confirm Payment

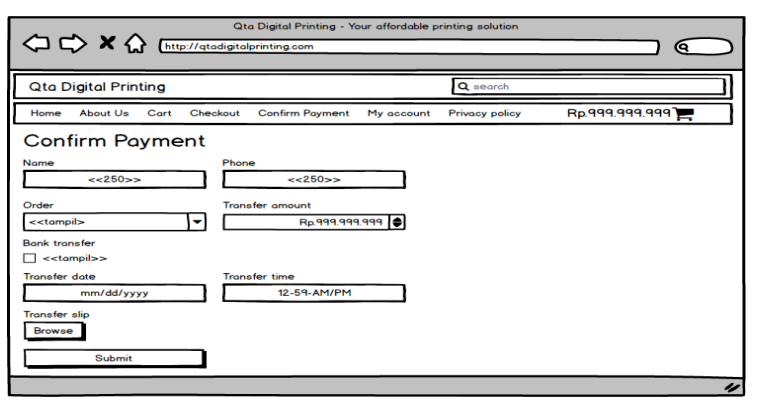

Gambar 17. Rancangan Layar Confrim Payment

Rancangan layar confirm payment memiliki textbox name, phone, order, transfer amount, transfer date dan transfer time.

\subsection{Strategi SEO}

Penggunaan SEO website merupakan hal penting untuk meningkatkan traffic pada website ecommerce. Berikut strategi SEO yang digunakan pada Q-ta Digital Printing :

a. Nama Produk dan Kata Kunci
Spanduk Flexi Jerman 4x2 Meter Murah Daerah Kota Depok

Permalink: https://atadigitalprinting.com/product/spanduk-flexi-je....aerah-kota-depok/ Edit

Gambar 18. Nama Produk Dan Kata Kunci

Menentukan kata kunci yang sering dicari pada search engine dengan menyesuaikan dengan nama produk. Contoh kata kunci yang sering digunakan adalah jual, murah, berkualitas, dimana produk itu dijual (contoh: Kota Depok).

b. Deskripsi Produk

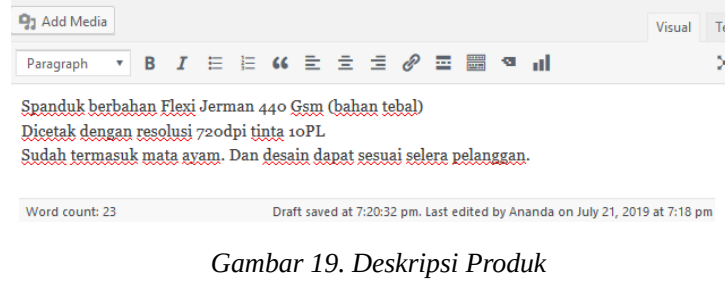

Deskripsi produk menggunakan bahasa yang mudah dimengerti oleh mesin pencari dan pelanggan yang akan melakukan transaksi, serta jauhi deskripsi produk yang memungkinkan dicap sebagai plagiat oleh mesin pencari dari website lain.

\section{c. Meta Description}

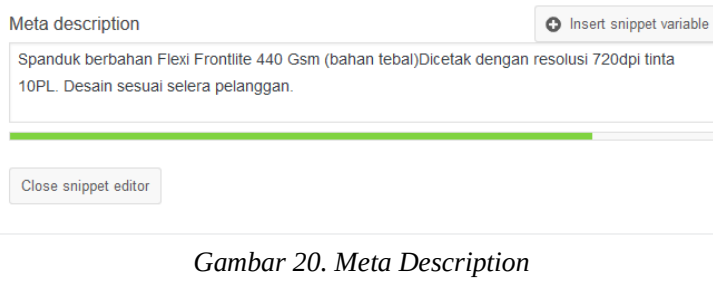

Meta description adalah deskripsi yang digunakan oleh search engine untuk menentukan meta description yang dibuat relevan dengan deskripsi produk pada halaman website.

d. Hasil SEO

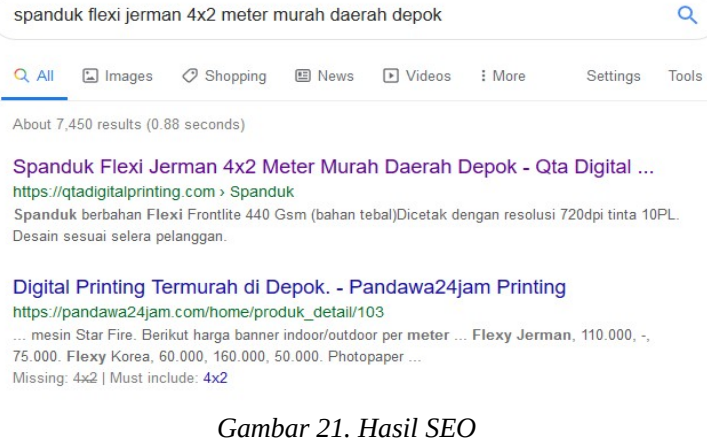

Gambar 21 menunjukkan hasil SEO yang diakses pada tanggal 26 Juli 2019 jam 14:35 WIB. 


\subsection{Marketing}

a. Instagram

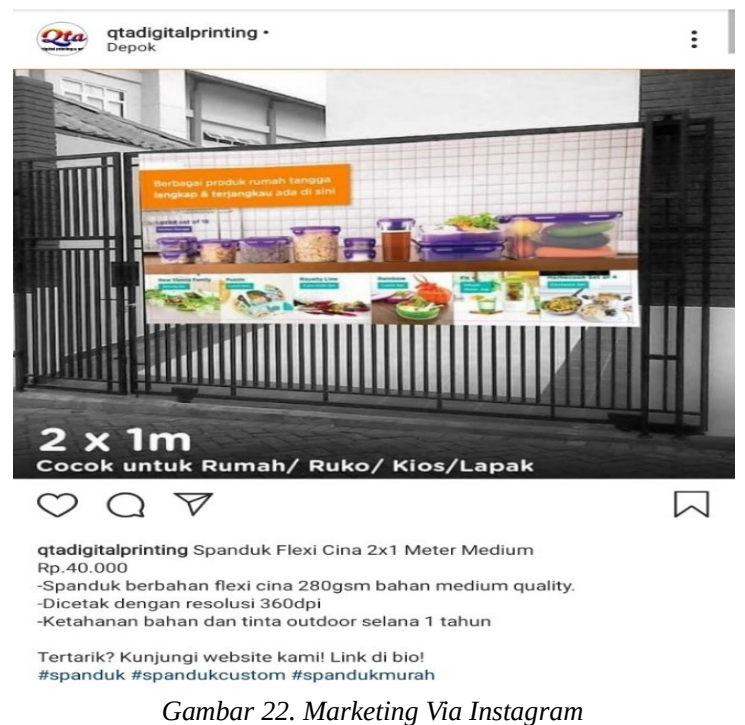

Marketing melalui instagram dengan cara memosting produk dan berperan sebagai etalase produk yang dijual pada website e-commerce. Penempatan link website pada bio akun Q-ta Digital Printing berfungsi sebagai backlink yang akan membantu proses SEO.

b. Facebook

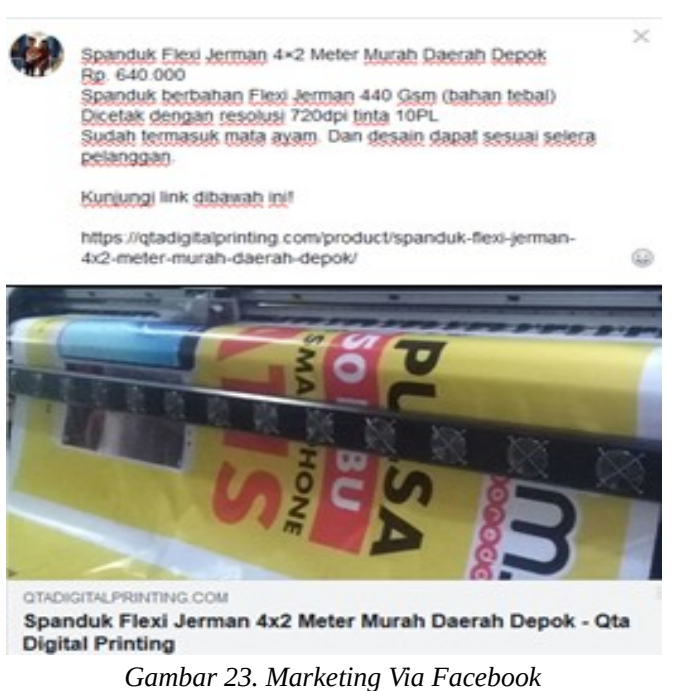

Marketing via facebook dengan cara menuliskan deskripsi produk yang dijual dan menaruh link website e-commerce sebagai backlink yang membantu proses SEO.

c. Twitter

\section{Q1) ananda}

Spanduk Flexi Jerman 4×2 Meter Murah Daerah Depok Rp640,000.00

Spanduk berbahan Flexi Jerman 440 Gsm (bahan tebal)

Dicetak dengan resolusi $720 \mathrm{dpi}$ tinta 10PL

Sudah termasuk mata ayam. Dan desain dapat sesuai

selera pelanggan.

\section{Kunjungi link di bawah ini!}

Translate Tweet

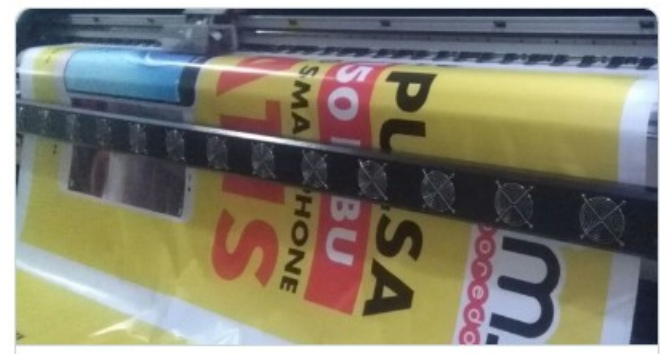

Spanduk Flexi Jerman $4 \times 2$ Meter Murah Daerah Depok - Qta Digital Printing

Spanduk berbahan Flexi Frontite 440 Gsm (bahan tebal)Dicetak dengan resolusi 720dpi 9 quPL Desain sesuai selera petanggan.

If qtadigitalprinting com

Gambar 24. Marketing Via Twitter

Marketing pada media sosial twitter pada Gambar 24 dengan cara mendeskripsikan produk yang dijual dan memberikan link produk di website e-commerce.

\section{KESIMPULAN}

Kesimpulan dari perancangan website $e$ commerce dengan CMS pada Q-ta Digital Printing adalah, dengan diterapkannya website e-commerce, penjualan spanduk pada Q-ta Digital Printing meningkat dan tidak hanya datang dari domisili Kota Depok yang bisa dilihat melalui menu laporan pengiriman pada dashboard admin dan mempermudah transaksi secara online. Penerapan strategi promosi melalui pemberian diskon pada website, promosi media sosial, serta penerapan Search Engine Optimization (SEO) meningkatkan calon pelanggan yang akan melakukan transaksi pada website. Dengan adanya fitur cetak laporan penjualan bulanan pada dashboard admin, pemilik dapat dengan mudah melihat dan mencetak laporan penjualan tiap bulannya.

\section{DAFTAR PUSTAKA}

[1] A. P. Widodo, P. B. Santoso, And Z. Darmawan, "Perancangan Website E-Commerce Sebagai Upaya Peningkatan Penjualan Produk Pada Toko Mebel Dengan Menggunakan Tool Opencart (Studi Kasus Di Toko Mebel Fortuna),” J. Rekayasa Dan Manaj. Sist. Ind., Vol. 2, No. 6, , 2015, Pp. 1272-1283. 
[2] Hidayatullah, And M. Y. Saeputra, “Analisis Model Bisnis Pada Kafe Fruitea Holic Dengan Pendekatan Business Model Canvas” Vol. 3, No. 3, 2016, Pp. 2756-2764.

[3] B. Soepeno, And D. A. Praditya, "Penggunaan Aplikasi CMS Wordpress Untuk Merancang Website Sebagai Media Promosi Pada Maroon Wedding Malang,” Akuntansi, Ekon. Dan Manaj. Bisnis, Vol. 2, No. 1, 2014, Pp. 63-69.

[4] S. Handayani, "Perancangan Sistem Informasi Penjualan Berbasis E-Commerce Studi Kasus Toko Kun Jakarta,” Ilk. J. Ilm., Vol. 10, No. 2, 2018, P. 182.

[5] R. Kurniawan And S. N. Anwar, "Membangun Situs E-Commerce Penjualan Dan Pemesanan Miniatur Bus Menggunakan Metode Waterfall,” Pros. Sintak 2017, 2017, Pp. 335-340.

[6] A. Ghina, And I. Siti Khodijah, "Analisis Pengembangan Usaha Mikro Kecil Menengah (UMKM) Pada Pengrajin Kursi Sofa Cipacing, Jatinangor Dengan Pendekatan Business Model Canvas Analysis,” Anal. Pengemb. Usaha Mikro Kecil Menengah Pada Pengrajin Kursi Sofa Cipacing, Jatinangor Dengan Pendekatan Bus. Model Canvas, Vol. 9, No. 2, 2016, P. 10. 